\title{
Analysis of factors affecting pre-weaning and post-weaning daily gains in Nigerian
} breeds of sheep

${ }^{1}$ Dafur, B. S. and Mbap, S. T. ${ }^{2}$

${ }^{I}$ Department of Animal Production, University of Jos, Jos.

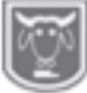

${ }^{2}$ Department of Animal Production, Abubakar Tafawa Balewa University,

Bauchi.

Abstract

Corresponding author: bdafur70@gmail.com; +2348036085311

Sheep play significant role in the socio-economic life of the large human population. Improving the productivity of sheep through selection and breeding would require understanding of their growth characteristics. This study was conducted to assess the preand post-weaning daily weight gains (ADG) of four Nigerian sheep breeds and some nongenetic factors affecting them. Pre-and post-ADG were measured in 33, 34, 43 and 47 lambs of Balami, Uda, WAD and Yankasa ewes respectively, and analyzed to determine the effect of breed, sex, year, season, parity, and birth type. At the pre-weaning stage, Balami and Uda had similar gains (91.89g vs. 92.44g) which were higher than that of Yankasa (74.22g) which was in turn higher than that of WAD (62.44g). During the post weaning stage, Balami gained most (77.19g), followed by Uda (71.12g), and Yankasa (59.37g) while WAD still maintained the lowest rate of gain (55.15g). Male sheep had higher ADG than females, $100.7 \mathrm{~g} v \mathrm{~s} .87 .8 \mathrm{~g}$ at pre-; and 65.67 vs. $58.15 \mathrm{~g}$ at post weaning. However, sex within breed analysis revealed nonsignificant influence of sex in all breeds except WAD at pre-weaning stage but males maintained better $(p<0.01)$ rates of gain post-weaning. Pre-ADG decreased with increased litter size. Lambs born at first parity gained more (85.00g) than subsequent parity lambs. Season and year had no significant effect on both pre- and post-weaning gains. It is concluded that breed, sex, birth type and parity influenced average daily gain in sheep.

Keywords: breed, sheep, average daily gains, non-genetic

\section{L'Analyse des facteurs affectant les gains quotidiens avant le sevrage et après le} sevrage chez les races nigérianes de moutons

\section{Résumé}

Les moutons jouent un rôle important dans la vie socio-économique de la population humaine. Pour améliorer la productivité des moutons grâce à la sélection et à l'élevage, il faudrait comprendre leurs caractéristiques de croissance. Cette étude a été menée pour évaluer les gains de poids quotidiens avant et après le sevrage (le 'ADG') de quatre races de moutons nigérians et certains facteurs non génétiques qui les affectent. Le Pré- et le post'ADG' ont été mesurés dans 33, 34, 43 et 47 agneaux de Balami, Uda, WAD et Yankasa brebis respectivement, et analysés pour déterminer l'effet de la race, sexe, année, saison, parité, et le type de naissance. Au stage de pré-sevrage, Balami et Uda ont connu des gains similaires (91,89 g contre 92,44 g) supérieurs à ceux de Yankasa (74,22 g), ce qui est à son tour supérieur à celui de WAD (62,44 g). Au cours de l'étape post-sevrage, Balami a gagné le plus (77,19 g), suivi par Uda (71,12 g) et Yankasa (59,37 g) tandis que WAD a maintenu le taux de gain le plus bas $(55,15 \mathrm{~g})$. Les moutons mâles avaient un ADG plus élevé que les femelles, 100,7 $\mathrm{g}$ contre 87,8 g à l'avant; et 65,67 contre 58,15 g au sevrage après le sevrage. Cependant, le sexe dans l'analyse de race a indiqué l'influence non significative du sexe dans toutes les races excepté WAD au stade de pré-sevrage mais les mâles ont maintenu de 
meilleurs taux $(p<0.01)$ de gain après le sevrage. Le pré-ADG a diminué avec l'augmentation de la taille des portées. Les agneaux nés à la première parité ont gagné plus $(85,00 \mathrm{~g})$ que les agneaux parité subséquents. La saison et l'année n'ont eu aucun effet significatif sur les gains avant et après le sevrage. On conclut que la race, le sexe, le type de naissance et la parité influençait le gain quotidien moyen chez les moutons.

Mots-clés: race, moutons, gains quotidiens moyens, non génétiques

\section{Introduction}

Sheep are raised in a wide range of agroclimatic areas in West Africa (Wilson, 1992). In Nigeria, they play significant role in the socio-economic life of the large human population. They are slaughtered during ceremonies and festivals. They also serve as ready cash for small farmers. Attempts to increase their productivity especially, through selection and breeding would require a comprehensive understanding of their growth traits. Bela and Haile (2009) stated that fast growth performance is capable of allowing sheep to breed early and contribute more lambs in their lifetime. Lambs that are fast in growth reach market weight early and bring quicker income to farmers. Iyiola-Tunji (2012) stated that average daily gain (ADG) is a significant factor in assessing growth rates in livestock. Gipson (1996) and Luginbuhl (1998) opined that growth of small ruminants can be divided into pre-weaning ADG and post-weaning ADG. Maternal environment and ability were reported (Ekiz, 2005; Maestripieri and Mateo, 2009) to have higher effects on growth preweaning while genetic potentials have higher effect post-weaning. The major component of maternal environment is milk yield (Bradford, 1972; Lewis and Beatson, 1999) but mothering ability which includes a number of other factors, also have significant effects on the physical environment of the young (Benyi et al., 2006). Reports on pre- and post-weaning growth characteristics of sheep are disparate in literature (Senou et al., 2009). Also, only a few studies have elaborated on the non-genetic factors influencing these traits. The purpose of this study is to assess the pre and post weaning average daily weight gains of four Nigerian sheep breeds and some non-generic factors affecting them.

\section{Materials and methods \\ Location and climate}

The research was carried out in Pankshin, Jos Plateau. The Jos Plateau has been described by PADP (2000), and WWF (2001). It is a pear-shaped upland located in the middle of Nigeria between latitude $8^{\circ}$ and $10^{\circ}$ north and longitudes $7^{\circ}$ and $11^{\circ}$ east, at an average attitude of $1,200 \mathrm{~m}$ above sea level and reaches the highest peak in the Shere Hills where it stands at $1,766 \mathrm{~m}$. The upland stretches for approximately $104 \mathrm{~km}$ from north to south and $80 \mathrm{~km}$ from east to west covering an area of about $8,600 \mathrm{~km}^{2}$ ( 860,000 hectares). It is characterised by rocky hills separated by extensive plains, exhibiting a variety of land forms which provide excellent picnic resorts. It has near temperate climate with average monthly temperatures ranging between $18^{\circ}$ and $25^{\circ} \mathrm{C}$. It experiences an average humidity of $60 \%$ and rainfall of $1,400 \mathrm{~mm}$. Most of it is covered by extensive grassland and few trees. Most of the trees are exotic such as eucalyptus. Light forests are however still found along some water courses. Mbap and 


\section{Dafur and Mbap}

Ngere (1989) therefore aptly described the vegetation as montane. The grasses are generally green and nutritive during rainy season (April- October) but less so during the dry season (November - March).

\section{Sheep used}

The study used 33, 34, 43 and 47 Balami, Uda, West African Dwarf (WAD) and Yankasa lambs respectively. The lambs were offspring of an initial research stock of 6 ewes each of Balami and Uda, and 10 each of WAD and Yankasa which were kept with a ram of their respective breeds at the Research Farm of Federal College of Education Pankshin Plateau State over a period of 38 months. The Uda and Balami were bought from Railway market in Bauchi, North Eastern Nigeria while the Yankasa and WAD were sourced from local farmers and markets within Plateau.

\section{Sheep management}

At the research station, sheep were housed in pens constructed with concrete blocks, floored and roofed with corrugated iron sheets. The ewes and a breeding ram of the same breed were kept together. Few days to lambing pregnant ewes were isolated and housed in a well littered lambing pen. After lambing, all necessary cleaning and identification processes were observed. New born lambs were kept with their ewes under close observation for 24 hours to ensure that they were suckled with colostrums. Ewes were allowed to graze without their lambs after three weeks of lambing. Throughout the period of the experimental study (November, 2011 December, 2014), animals were grazed separately by sex on locally available pasture from 9:00am to 5:00pm. Crop residues such as legumes and corn stalks, leafy shrubs and herbs were made available. In the evening they were returned to the pen and provided with salt lick and supplementary maize offals, groundnut haulm, cowpea and corn husks. Drinking water was supplied ad libitum. Before the start of experiment, animals were dewormed twice at monthly intervals with levamisole and albendazole at dose rates of 7.5 and $5.0 \mathrm{mg} / \mathrm{kg}$ body weight respectively and no deworming thereafter. Asuntol solution bath was carried out at quarterly intervals to control ectoparasites. Prophylactic treatment with oxytetracycline long acting (LA) was undertaken twice a year to prevent bacterial infections.

\section{Measurement of growth rate and statistical analysis}

Body weights were measured in kilogramme using the Salter scale. The weights measured included at birth (within the first day), monthly up to the 12th and at weaning, 90th day. Pre- and post-weaning average daily weight gains (ADG) were calculated in grammes using the following expressions:

Pre $-A D G(A D G 90)=$ Weight at $90-$ weight at birth/90 x 1000

Post $-A D G(A D G 90)=$ Weight at 360 day weight at 90 days $/ 270 \times 1000$

Data generated were analyzed using the General Linear Model (GLM) of SPSS (Statistical Packages for Social Sciences, 2013) version 22.0. Differences among breed, sex, year, season, parity, and birth type in terms of pre and post weaning average daily gain, ADG were determined. Ryan-Einot-Gabriel-Welsch post hoc-test was performed to separate any more-thantwo means that were statistically different. The statistical model used is;

$\mathrm{Y}_{\mathrm{ijklpqr}}=\mu+\mathrm{G}_{\mathrm{i}}+\mathrm{S}_{\mathrm{j}}+\mathrm{P}_{\mathrm{k}}+\mathrm{B}_{1}+\mathrm{N}_{\mathrm{l}}+\mathrm{E}_{\mathrm{q}}+$ $\mathrm{e}_{\mathrm{ijklnlqr}}$

Where:

$\mathrm{Y}_{\mathrm{ijklpqr}}=$ observable characteristic;

$\mu=$ overall mean;

$\mathrm{G}_{\mathrm{i}}=\mathrm{i}^{\text {th }}$ effect of breed $(\mathrm{i}=1,2,3,4)$;

$S_{j}=j^{\text {th }}$ effect of $\operatorname{sex}(j=1,2)$;

$\mathrm{P}_{\mathrm{k}}=\mathrm{k}^{\text {th }}$ effect of parity $(\mathrm{k}=1,2,3)$;

$\mathrm{B}_{1}=1^{\text {th }}$ effect of birth type $(1=1,2,3)$;

$\mathrm{N}_{1}=\mathrm{p}^{\text {th }}$ effect of season $(\mathrm{p}=1,2,3,4)$;

$\mathrm{E}_{\mathrm{q}}=\mathrm{q}^{\text {th }}$ effect of year $(\mathrm{q}=1,2,3)$ and 
Table 1: least squares means (g) pre and post-weaning average daily gains (ADG) in sheep

\begin{tabular}{|c|c|c|c|}
\hline & \multicolumn{2}{|c|}{ Pre-weaning ADG } & Post-weaning ADG \\
\hline Overall & 88.11 & 72.30 & \\
\hline \multicolumn{4}{|l|}{ Breed } \\
\hline Balami & $91.89^{\mathrm{a}}$ & $77.19^{\mathrm{a}}$ & \\
\hline Uda & $94.44^{\mathrm{a}}$ & $71.12^{\mathrm{b}}$ & \\
\hline WAD & $62.44^{\mathrm{c}}$ & $55.15^{\mathrm{d}}$ & \\
\hline Yankasa & $74.22^{\mathrm{b}}$ & $59.37^{\mathrm{c}}$ & \\
\hline \multicolumn{4}{|l|}{ Sex } \\
\hline Male & $100.7^{\mathrm{b}}$ & $65.67^{\mathrm{b}}$ & \\
\hline Female & $87.78^{\mathrm{a}}$ & $58.15^{\mathrm{a}}$ & \\
\hline \multicolumn{4}{|c|}{ Sex within breed } \\
\hline \multicolumn{4}{|c|}{ Balami } \\
\hline Female & 98.00 & $59.30^{\mathrm{a}}$ & \\
\hline Male & 98.56 & $82.37 b$ & \\
\hline \multicolumn{4}{|l|}{ Uda } \\
\hline Female & 91.44 & $57.00^{\mathrm{a}}$ & \\
\hline Male & 87.56 & $74.89^{\mathrm{b}}$ & \\
\hline \multicolumn{4}{|l|}{ WAD } \\
\hline Female & $62.33^{\mathrm{a}}$ & $44.78^{\mathrm{a}}$ & \\
\hline Male & $76.22^{\mathrm{b}}$ & $60.22^{\mathrm{b}}$ & \\
\hline \multicolumn{4}{|l|}{ Yankasa } \\
\hline Female & 62.0 & $59.96^{\mathrm{a}}$ & \\
\hline Male & 59.56 & $71.93^{b}$ & \\
\hline \multicolumn{4}{|l|}{ Birth type } \\
\hline Single & $86.78^{\mathrm{a}}$ & 69.04 & \\
\hline Twins & $82.11^{\mathrm{b}}$ & 71.48 & \\
\hline Triplet & $77.11^{\mathrm{c}}$ & 72.89 & \\
\hline \multicolumn{4}{|l|}{ Parity } \\
\hline $1^{\text {st }}$ & $85.00^{\mathrm{a}}$ & 72.70 & \\
\hline $2^{\text {nd }}$ & $75.11^{\mathrm{b}}$ & 75.26 & \\
\hline $3 \mathrm{rd}$ & $78.44^{b}$ & 72.26 & \\
\hline \multicolumn{4}{|l|}{ Season } \\
\hline Early rainy & 95.44 & 60.33 & \\
\hline Late rainy & 96.22 & 58.59 & \\
\hline Early dry & 94.22 & 61.11 & \\
\hline Late dry & 100.00 & 60.33 & \\
\hline \multicolumn{4}{|l|}{ Year } \\
\hline 2012 & 94.33 & 62.19 & \\
\hline 2013 & 89.44 & 61.22 & \\
\hline 2014 & 90.00 & 63.04 & \\
\hline
\end{tabular}

Means in the same column with different superscripts differ significantly, $(\mathrm{p}<0.05)$

$\mathrm{e}_{\mathrm{ijklnlqr}}=$ Random error effect.

\section{Results and discussion}

Pre- and post-weaning weight gains The pre- and post-weaning average daily gains (ADG) least square were as presented in
Table 1. Animals gained more weight before than after weaning. Breed significantly $(p<0.001)$ influenced pre- and post-weaning gains. At the pre-weaning stage, Balami and Uda had similar gains (91.89g vs. 92.44g) which were higher than 


\section{Dafur and Mbap}

that of Yankasa (74.22g) which was in turn higher than that of WAD (62.44g). During the post weaning stage, Balami gained most (77.19g), followed by Uda (71.12g), and Yankasa (59.37g) while WAD still maintained the lowest rate of gain $(55.15 \mathrm{~g})$. Similarly, sex also had significant $(\mathrm{p}<0.01)$ influence at both pre- and post-weaning stages. The males gained more than the females, $100.7 \mathrm{~g}$ vs. $87.8 \mathrm{~g}$ at pre-; and 65.67 vs. $58.15 \mathrm{~g}$ at post weaning. However, sex within breed analysis revealed nonsignificant influence of sex in all breeds except WAD at pre-weaning stage but males maintained better $(p<0.01)$ rates of gain post-weaning. The effect of lamb's birth type was significant $(\mathrm{p}<0.05)$ at prebut not at post-weaning stage. Lambs born as singles had the highest gains, $86.78 \mathrm{~g}$, followed by twins, $82.11 \mathrm{~g}$, while triplets had the lowest, 77.11g. Similarly, parity had significant $(\mathrm{p}<0.05)$ influence on preweaning rates of gain only. Lambs born at first parity gained more $(85.00 \mathrm{~g})$ than second and third parity lambs which had similar gains (75.11 vs. 78.44). Season and year however had no significant effect on both pre- and post-weaning gains.

Breed influence on pre- and post- weaning average daily gain (ADG) in this study is consistent with previous reports (Cambella et al., 1990; Arora et al., 1996). These authors reported significant breed differences in liveweight gains of sheep from birth to weaning, Similarly, Taiwo et al. (1982) observed sheep significant breed difference in post weaning rate of gain. Fasae et al. (2012) observed faster growth in Yankasa lambs than WAD. However, the non-significant difference observed between Uda and Balami lambs in preweaning ADG is contrary to the findings of Momoh et al. (2013) and Rotimi et al. (2013) who reported higher value for the two stages in Balami than Uda in the SemiArid region of Nigeria. The difference in findings could be due to ecological and management differences. For the postweaning $\mathrm{ADG}$, the findings are in consonance. The generally higher pre and post weaning ADG found in males than females in the present study agree with the reports of Momoh et al. (2013) and Rotimi et al. (2013). Fasae et al. (2012) found that males were superior in pre and postweaning ADG compared to females among Balami and Uda breeds. Differences in sex chromosome, probably related to growth, physiological characteristics and sex hormones could lead to variation growth (Momoh et al., 2013). Oestrogen has a limited effect on the growth of long bones in females and could be the reason for their smaller and lighter body weights (Rashidi et al., 2008). Hafez (1962) ascribed higher growth in males to their hormones which have anabolic effect. Males probably begin to secret androgenic substances very early and thus grow and develop faster than females (Ebangi et al., 1996). In the present study, pre-weaning ADG decreased with increased litter size. This is similar to some previous reports (Gbangboche et al., 2005; Momoh et al., 2013). Momoh et al. (2013) also found that singles were superior to multiple born lambs in both pre and post weaning ADG in Uda and Balami sheep. Similarly, Gbangboche et al. (2004) reported that single lambs exhibited higher ADG than twin lambs at the pre-weaning stage irrespective of genotype (WAD and West African long legged $x$ WAD) and the difference between pre and post ADG decreased with increased lambs age. Similar effect of birth type has been documented for WAD (Ambruster and Metz, 1991; Abassa et al., 1992); West African long legged (Ebangi et al. 1996; Ebangi et al., 2001) and Rahmani and Finn (Gaafar et al., 2012) breeds. This could be due to insufficient milk supply for twins/multiples as compared to singles during the pre-weaning stage. Dam parity significantly influenced pre- but not post 
weaning ADG. Pre-weaning ADG increased with number of parity. This finding corroborates some earlier reports (Ambruster and Metz, 1991; Yapi-Gnaore et al., 1997; Gbangboche et al., 2005; Momoh et al., 2013). The efficiency of preweaning growth was also reported by Thiruvenkadan et al. (2011) to decrease with the advancement of parity. Relative competition for nutrients between the still growing young dams (i.e 1st Parity dams) and the developing foetus, may be the cause of depressed growth performance in lambs. However, Benyi et al. (2006) and Gbangboche et al. (2006) found no significant effect of parity on pre-weaning growth rate.In the present study, season and year did not influence both pre and post weaning ADG. For season, this finding contradicts the report of Momoh et al. (2013). The authors stated that lambs born in the rainy season grew faster than their dry season counterparts. On the flip side, Benyi et al. (2006) observed that pre-weaning growth rate was significantly faster in lambs born in the dry season but the reverse was true for the post-weaning aspect. For year, the present finding is in consonance with the authors. Gafaar et al. (2012) did not observe any influence of year on ADG. However, other workers (Adeleye, 1984; Ebangi et al., 2001; Gbangboche et al., 2005) found that year influenced lambs' growth. The authors suggested that influence of year may be due to variations in the production environment (management, herdsmen skills, forage availability and other environmental changes).

\section{Conclusions}

In Nigerian sheep, breed and sex generally influence average daily weight gains (ADG). Pre- weaning ADG is affected by only litter size (birth type)) and parity. Postweaning $\mathrm{ADG}$ are not affected by some non-genetic factors (birth type, parity, season and year).

\section{References}

Abassa, K. P., Pessinaba, J. and Adeshola-Ishola, A. 1992. Croissance pre-sevrage des agneaux Djallonke au Centre de Kolokope (Togo). Revue d'Elevage et de Medecine Veterinaire des Pays tropicaux, 45: 49-54

Adeleye, I. O. A. 1984. Seasonal effects on lamb production under tropical conditions. Nigerian Journal of Animal Production, 11: 168-174.

Ambruster, T. Peters, K. J. and Metz, T. 1991. Sheep production in the humid zone of West Africa: IIGrowth performance and live weights of sheep in improved and traditional production production system in C'ote-d'Ivoire. Journal of Animal Breeding and Genetics, 108: 210-219.

Arora, D. N., Singh, B., Kaira, S., Balaine, D. S. 1996. Studies on growth and body weights in different breeds of sheep. Livestock Adviser 11(11): 29-31.

Bella, B. and Haile, A. 2009. Factors affecting growth performance of sheep under village management conditions in the south western part of Ethiopia. Livestock Research for Rural Development. Volume 21, Article. Retrieved October 6, 2011, $\begin{array}{lllll}\mathrm{f} & \mathrm{r} & \mathrm{o} & \mathrm{m} & \text { : }\end{array}$ http://www.lrrd.org/1rrd21/11/bela 21189.htm

Benyi, K., Norris, D., Karibo, N. and Kgomo, K. 2006. Effect of genetic and environmental factors on preweaning and post-weaning growth in West African crossbred sheep. Tropical Animal Health and Production, 38(7-8): 547-558.

Bradford, G. E. 1972. The role of maternal effects in animal breeding. VII: Maternal effects in sheep. Journal of Animal Science, 35: 1324-1334. 
Cambella, J., Martinaz, N., Gonalez, J. 1990. Study of some factors affecting birth and weaning weights of lambs. Animal Breeding Abstract 48:

Ebangi, A. L., Njoya, A., Ngo-Tama, A. C., Awa, D. N. and Bah, D. A. 2001. Genetic and phenotypic parameters of birth weight traits in Fulbe sheep in Cameroon. Revue d'Elevage et de Medicine Veterinaire des Pays Tropicaux, 54(2): 147- 151.

Ebangi, A. L., Nwakalor, L. N., Mba, D. A., Abba, D. 1996. Factors affecting the birth weight and neonatal mortality of Massa and Fulbe sheep breed in a hot and dry environment of Cameroon. Revue d'Élevage et de Medecine Vétérinaire des Pays Tropicaux, 49:349-353.

Ekiz, B. (2005). Estimates of maternal effects for pre- and post-weaning daily gain in Turkish Merino lambs. Turkish Journal of Animal Science, 29: 399-407.

Fasae, O. A., Oyebola, A. O., Adewumi, O. O. and James, I. J. 2012. Factors affecting birth and weaning weight in lambs of Yankasa, West African Dwarfs and their crosses. Journal of Agricultural Science and Environment, 12 (2): 89-95.

Gaafar, H. M. A., Hafsa, F. H., Youssf, M. T. and Shehab, E. 2012. Environmental factors affecting growth performance of growing lambs in Egypt. Archiva Zootechnica, 15(1): 15-29.

Gbangboche, A. B., Adamou-Ndiaye, M., Hounzangbe-Adote, S. M., Salifou, S., Farnir. F., Leroy, P. L. and Abiola, F. A. 2005. Evaluation of West African Dwarf (WAD) sheep and F1 crossed West African Long Legged (WALL) rams with
WAD ewes in Benin: Growth and survival traits. Accessed April 7, 2017, from:

Gbangboche, A. B., Alkoiret, T. I., Salifou, S., Farnir, F., Leroy, P. L. and Abiola, F. A. 2011. Growth pattern of purebred West African Dwarf sheep and its crosses with the West African long legged. Research Journal of Animal Sciences 5, 6-13.

Gbangboche, A. B., Youssao, A. K., Senou, M., Adamou-Ndiaye, M., Ahissou, A., Farnir, F., Abiola, F. A. and Leroy, P. L. 2006. Examination of non-genetic factors affecting the growth performance of Djallonke sheep in Sudanian zone at the Okpara Breeding Farm of Benin. Tropical Animal Health and Production, 38(1): 55-64.

Gipson, T. A. 1996. Breed capabilities and selection for meat production. In: Proceedings of the meat goat symposium. December 7, 1996. Upper Malboro, MD. pp 7-15.

Hafez, E. E. 1962. Reproduction in Farm Animals. (2nd edition). Lea and Febizer, Philadelphia

Iyiola-Tunji, A. O. (2007). Factors affecting growth traits and litter size of Red Sokoto goats in Shika, Zaria. Unpublished MSc. Thesis. Post Graduate School, Ahmadu Bello University, Zaria, Nigeria.

Lewis, R. M. and Beatson, P. R. 1999. Choosing maternal-effect models to estimate (co)variances for live and fleece weight in New Zealand Coopworth sheep. Livestock Production Science, 58: 137-150.

Luginbuhl, J. M. 1998. Breed of goats for meat production. Annual Report. Department of Animal Science, North Carolina State University, USA.pp 22-28.

Maestripieri, D. and Mateo, J. M. 2009. 
Maternal effects in mammals. University of Chicago Press. USA. 345 pp.

Mbap, S. T. and Ngere, L. O 1989. Productivity of Friesian cattle in a subtropical environment. Tropical Agriculture (Trinidad), 66 (2): 121 124.

Momoh, O. M., Rotimi E. A., and Dim, N. I. 2013. Breed effect and nongenetic factors affecting growth performance of sheep in semi-arid region of Nigeria. Journal of Applied Biosciences., 67: 53025307.

PADP. 2000. Plateau Agricultural Development Programme. House Journal, p13.

Rashidi, A., Mokhtari, M. S., SafiJahanshahi, A. and Abadi, M. R. M. 2008. Genetic parameters estimates of pre-weaning growth traits in Kermani Sheep. Small Ruminant Research, 74: 165-171.

Rotimi, E. A., Egahi, J. O. and Adeoye, A. A. 2013. Pre- and post-weaning performance of Uda and Balami in the semi-arid region of Nigeria. Scholarly Journal of Agricultural Science, 3 (2): 58-61.

Senou M, Tobada P, Dahouda M, Adandédjan C, Aboki V, Alimy S. and Tondji P. M. 2009. Pre- and post-weaning growth in Djallonké lambs. Livestock Research for Rural Development. Volume 21, Article \#81. Retrieved September $27, \quad 2020, \quad$ f $\mathrm{r}$ o m http://www.lrrd.org/lrrd21/6/seno 21081.htm
Taiwo, B. B. A., Ngere, L. O. and Adeleye, I. O.A. 1982. Comparative Growth Performance of Nigerian Dwarf Sheep and its Crosses with Permer, Uda and Yankasa. World Review of Animal Production, 28(1): 57-63.

Thiruvenkadan, A. K., Karunanithi, K., Muralidharan, J. and Babu, R. N. 2011. Genetic analysis of preweaning and post-weaning growth traits of Mecheri sheep under dry land farming conditions. AsianAustralasian Journal of Animal Sciences, 24(8): 1041-1047.

Wilson, R. T. 1992. Petits ruminants: production et resources genetiques en Afriaue tropicals. Etude FAO, Production et Dante Animals, 88: 133-139.

World Wildlife Fund (WWF) 2001. Plateau forest Grassland Mosaic (AT1010). World Wildlife Fund Scientific Report. 2 pp.

Yapi-Gnaore, C. V., Oya, A., Rege, J. E. O. and Dagnogo, B. 1997. Analysis of an open nucleus breeding programme for Djallonke sheep in the Ivory Coast. 1: examination of non-genetic factors. Animal Science, 64: 291300 .

Received: $4^{\text {th }}$ November, 2020 Accepted: $15^{\text {th }}$ February, 2021 